\title{
Satellite imagery detection of land destruction in Klapanunggal Karst Landscape induced by limestone surface mining
}

\author{
Ridwan Arif Pambudi ${ }^{1,4^{*}}$, Ahmad Bahtiazhar Rodhial Falah ${ }^{2}$, Ari Naldi ${ }^{3,4}$, Nurul Falahiyyah \\ Bahri ${ }^{4}$, Irene Swastiwi Viandari Kharti ${ }^{4}$, Muhammad Akbar Hariadi ${ }^{4}$, and Ade Luthfi ${ }^{4}$ \\ ${ }^{1}$ Department of Geography, Faculty of Mathematics and Natural Sciences, Universitas Indonesia, \\ Depok, 16424, Indonesia \\ ${ }^{2}$ Acintyacunyata Speleological Club, Yogyakarta, 55171, Indonesia \\ ${ }^{3}$ School of Environmental Science, Universitas Indonesia, Jakarta, 10430, Indonesia \\ ${ }^{4}$ Karst Progressive Research Group, Depok, 16412, Indonesia
}

\begin{abstract}
Limestone mining activities in the Klapanunggal Karst Landscape were carried out at surface level. This method induced several adverse impacts on the environment. This study aimed to detect land destruction in the Klapanunggal Karst Landscape triggered by open limestone mining on the surface in the 2014-2020 period. The supervised classification method of Maximum Likelihood Estimation (MLE) was used to detect the change in land cover from Landsat 8 imagery, and Differential Interferometric Synthetic Aperture Radar (DInSAR) was applied to detect the change in landform from Sentinel 1A imagery. As a result, between 2014 to 2020, open limestone mining in the Klapanunggal Karst Landscape was confirmed to have a significant impact on the land cover changes in Klapanunggal, from an area with full of vegetation to a mining area with 4.0 $\mathrm{x} 10^{6} \mathrm{~m}^{2}$ wide, and eroded landform with a dominant land deformation rate in the range of -47.75 to $-39.50 \mathrm{~cm} /$ year and -39.50 to $-31.25 \mathrm{~cm} / \mathrm{year}$. The limestone mining activity in the period of $2014-2020$ was estimated to have mined limestone with a volume of $30.7 \times 10^{6} \mathrm{~m}^{3}$. Limestone surface mining has destructed Klapanunggal Karst Landscape, further research was needed to examine the adverse impacts on the hydrogeological system.
\end{abstract}

\section{Introduction}

Limestone is one of the most needed mineral resources in various sectors [1-3]. In general, limestone mining is carried out openly at surface level (open pit or open cast mining) [4]. This method has been shown to destroy land cover, overexploit water, pollute water, soil, and air, reduce flora and fauna biodiversity, trigger soil erosion, and change the landform of karst landscapes [5-7].

Given the high population growth and the adverse impact on the environment, some limestone mining in North America has started to switch to underground mining methods

* Corresponding author: ridwan.arif@ui.ac.id 
$[4,8]$. Nevertheless, underground mining still threatens environmental sustainability because it can trigger land subsidence and damage the hydrogeological system of karst landscapes $[9,10]$. In Indonesia, the open mining method is still cannot be replaced. One of the mining sites that use this method and has been going on since 1975 is the open mining limestone area in the Klapanunggal Karst Landscape [11,12].

Considering that limestone mining activities in the Klapanunggal Karst Landscape are still carried out openly at surface level and operating on an industrial scale, it is possible to monitor land destruction in the mining area by utilizing remote sensing. Remote sensing with satellite platforms has developed rapidly since its first successful launch in 1960 [13]. It can be used as an extractive instrument and a tool for environmental conservation needs [14].

This study aims to detect land destruction in the Klapanunggal Karst Landscape due to limestone mining activities by reviewing aspects of land cover change and landform changes using a combination of multispectral optical satellite imagery and synthetic aperture radar (SAR) from 2014 to 2020. This research result can be used as a basis for conducting further research related to the impact of open limestone mining, which threatens the Klapanunggal Karst Landscape's sustainability.

\section{Method}

\subsection{Research area}

The Klapanunggal Karst Landscape dominantly stretches over Klapanunggal and Jonggol Sub-districts, Bogor Regency, West Java Province (Fig. 1).

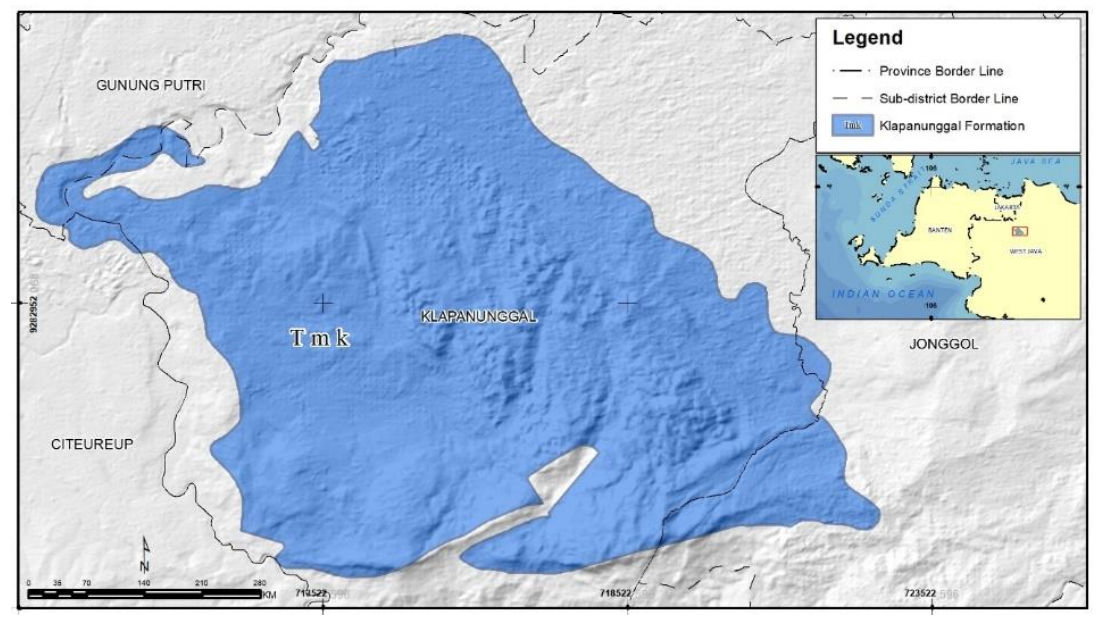

Fig. 1. Research area.

This karst landscape represents the dissolution process (karstification) within the Kalapanunggal Formation's limestone in the Bogor Basin. The limestone of the Klapanunggal Formation is grouped into the upper rock group of Pemali Beds, which represents the sedimentation age of the Lower Miocene-Middle Miocene with an estimated thickness of 2,000 meters in the middle and 550-1,200 meters in the northeast with index fossils of Cycloclypeus (Katacycloclypeus) annulatus Martin, Cycloclypeus sp, Lepidocyclyna sp, Myogypsina sp [15]. In addition, the Klapanunggal Karst Landscape was included in ten major karst areas in the northern part of the Java Tertiary Zone [16]. 
Lithologically, the Klapanunggal Formation is made up of reef limestone, sandstone insert, clay-limestone, and quartz sandstone. Based on the development of its lithofacies, the Klapanunggal Formation is divided into four lithofacies: boundstone facies, packstone facies, rudstone facies, and limestone breccias facies (based on the classification of Dunham, 1962 dan Embry \& Klovan 1971) [17]. This lithofacies diversion shows that the Klapanunggal Formation limestone was deposited in four different sedimentation environments.

The Klapanunggal Formation has an interfingering relationship with the Jatiluhur Formation, which is lithologically composed of clay-limestone and claystone with inserts of limestone, sandstone limestone, and slump deposits. The limestone inserts of the Jatiluhur Formation in several places are thick and very thick. It is not easy to distinguish the Jatiluhur Formation's limestone and the Klapanunggal Formation in some places because they often show karstification [18]. The Klapanunggal Karst Landscape is controlled by several anticline structures (anticlinoriums) with a northwest-southeast orientation. Apart from the anticline structures, the Klapanunggal Karst Landscape is also cut by the Citarik Fault, which has a northeast-southwest orientation.

\subsection{Materials}

In this study, land destruction due to limestone mining activities in the Klapanunggal Karst Landscape is viewed based on land cover changes and land formation. The land cover change was obtained from multispectral optical satellite imageries Landsat 8 provided by the United States Geological Survey (USGS) (downloaded at https://earthexplorer.usgs.gov) [19]. In contrast, landform change was obtained from SAR Sentinel 1A imageries which provided by the European Space Agency (ESA) (downloaded at https://asf.alaska.edu) [20]. The detailed information of the data above can be seen in Table 1 and Table 2.

Table 1. Landsat 8 detailed information.

\begin{tabular}{|c|c|c|}
\hline \multirow{2}{*}{ Parameters } & \multicolumn{2}{|c|}{ Description } \\
\hline & $13^{\text {th }}$ September 2014 & $27^{\text {th }}$ July 2020 \\
\hline Path/Frame & $122 / 64$ & $122 / 65$ \\
\hline Cloud Cover & $3.59 \%$ & $4.82 \%$ \\
\hline Sun Elevation & $61.62^{\circ}$ & $50.69^{\circ}$ \\
\hline Multispectral Spatial Resolution & 30 meters & 30 meters \\
\hline Panchromatic Spatial Resolution & 15 meters & 15 meters \\
\hline
\end{tabular}

Table 2. Sentinel 1A detailed information.

\begin{tabular}{|c|c|c|}
\hline \multirow{2}{*}{ Parameters } & \multicolumn{2}{|c|}{ Description } \\
\cline { 2 - 3 } & $\mathbf{8}^{\text {th }}$ October 2014 & $\mathbf{5}^{\text {th }}$ September 2020 \\
\hline Beam Mode & IW & IW \\
\hline Acquisition Mode & SLC & SLC \\
\hline Path/Frame & $47 / 614$ & $47 / 614$ \\
\hline Flight Direction & Descending & Descending \\
\hline Polarization & VV & VV+VH \\
\hline Absolute Orbit & 2744 & 32494 \\
\hline
\end{tabular}

\subsection{Method}




\subsubsection{Land cover change}

In this study, information on land cover change of limestone mining in 2014-2020 was obtained by comparing the land cover classification results in 2014 and 2020. In producing the land cover classification, Landsat 8 imagery must go through the pre-processing and processing stage. The pre-processing stage aims to prepare raw data into ready-to-process data. The pre-processing stage consists of radiometric calibration, radiometric correction, adjustment of the image area coverage (spatial subset), and image enhancement.

This study's scope of radiometric calibration is to change the digital number (DN) value to the Top of Atmosphere (TOA) reflectance value that has not been corrected by the sun's angle (Equation 1). Radiometric correction aims to improve the image's visual quality and improve the image's pixel value due to radiometric errors [21]. Radiometric correction in this study was carried out by correcting the sun's angle following Equation (2) [21,22]. Image area adjustment aims to reduce data size so that data processing can be done quicker. Image sharpening using Gram-Schmidt Pan-sharpening aims to sharpen the spatial resolution of the image by fusing the multispectral band (bands 1-7) with the panchromatic band (band 8) so that the original spatial resolution of 30 meters is sharpened to 15 meters [21,23].

The processing stage, which aims to extract land cover information from data that is ready to be processed, is carried out using the supervised classification method. Several Landsat 8 RGB band combinations, including a healthy vegetation (bands 5,6, and 2), land/water (bands 5,6 , and 4), and urban false-color (bands 7,6, and 4) are displayed as a consideration to input the training data needed in the Maximum Likelihood Estimation (MLE) guided classification. The workflow for pre-processing and processing of land cover classification can be seen in Fig. 2.

Where:

$$
\rho \lambda=M \rho \cdot Q_{c a l}+A \rho
$$

$P \lambda=$ TOA reflectance which not corrected by the sun's angle yet

$M \rho=$ scale factor (Band-specific multiplicative rescaling factor)

$A \boldsymbol{\rho}=$ additional factor (Band-specific additive rescaling factor)

Qcal = Pixel value $(\mathrm{DN})$

Where:

$$
\rho \lambda^{\prime}=\rho \lambda / \operatorname{Cos} \cdot \theta
$$

$$
\begin{array}{ll}
\rho \lambda^{\prime} & =\text { TOA reflectance which corrected by the sun's angle } \\
\rho \lambda & =\text { TOA reflectance which not corrected by the sun's angle yet } \\
\theta & =\text { Sun's elevation angle }
\end{array}
$$

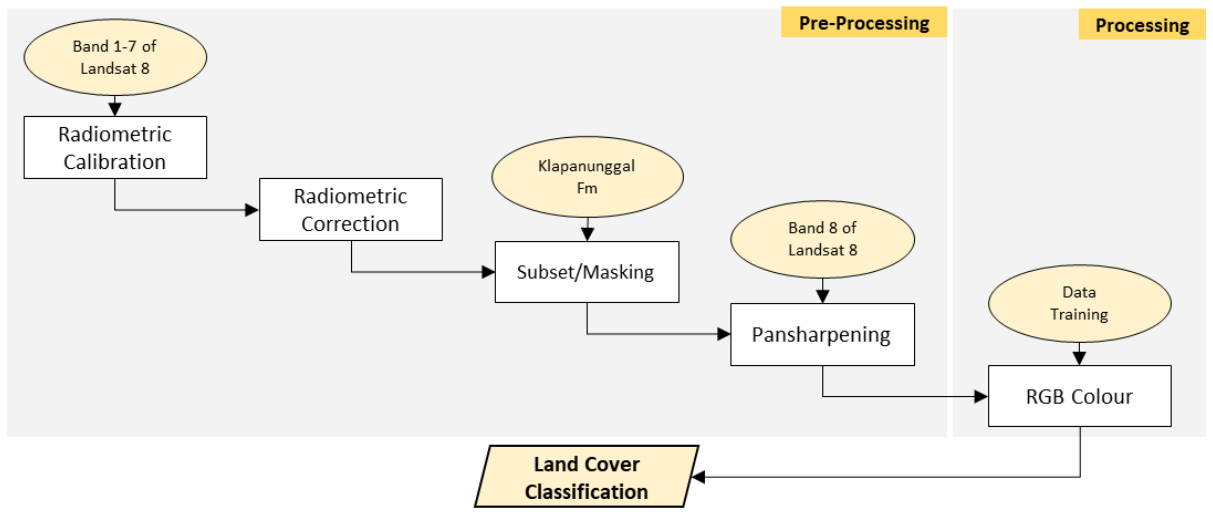


Fig. 2. Land cover classification workflow from Landsat 8 imagery.

\subsubsection{Landform change}

Changes in landform in this study were carried out through an estimated rate of land deformation approach. Each pixel in the Sentinel 1 image consists of amplitude and phase components [24]. The phase signal emitted by the SAR sensor is able to measure the distance between the sensor and the object (Earth's surface) $[25,26]$. Land deformation detection using Sentinel 1 image data was carried out using the Differential Interferometric Synthetic Aperture Radar (DInSAR) method. This method uses the available phase of two Sentinel 1 images acquired in the same area at different times [27]. The detailed calculation basis used in DInSAR is described in Equation (3) [28].

$$
\Delta \phi=\Delta \phi \text { flat }+\Delta \phi \text { height }+\Delta \phi \text { displacement }+\Delta \phi \text { atmosphere }+\Delta \phi \text { noise }
$$

Where;

$\Delta \phi$ flat

$\Delta \phi$ height

$\Delta \phi$ displacement : the part of the phase which represents the ground deformation measured along the line of sight (LOS);

$\Delta \phi$ atmosphere : The contribution of phase caused by the delay of radar wave propagation through the atmosphere;

\section{$\Delta \phi$ noise $\quad$ : Residual noise.}

In this study, the DInSAR method was processed using the Sentinel Application Platform (SNAP) software and the SNAPHU plugin. The first step in interferometric processing, two Sentinel 1A images, must be coregistered into a stack [29]. The Sentinel 1A image acquired on 8 October 2014 was designated as a slave image, while the Sentinel 1A image acquired on 5 September 2020 was designated as the master image. The second step, the interferogram stage, is carried out to eliminate the flat earth phase [29]. In the third step, to produce a single seamless image, the TOPCAR Deburst stage is applied [29]. The fourth step, the multi looking stage, is applied to produce a product with a particular image pixel size (this stage is optional) [30]. The fifth step, Goldstein Phase Filtering, is applied to increase the "signal-tonoise" ratio to be suitable for further unwrapping processing. In the sixth step, SNAPHU Unwrapping was applied to produce the unwrapped interferogram [31]. The steps to detect the complete land deformation rate can be seen in Fig. 3. Furthermore, the mined limestone volume can be estimated from the land deformation rate information by the following Equation (4).

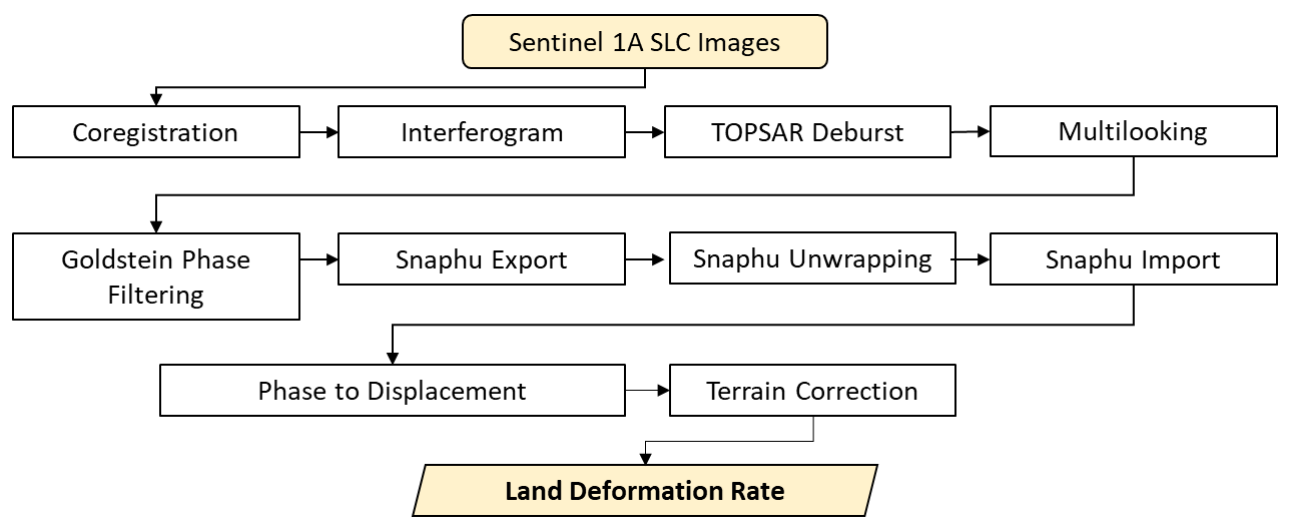


Fig. 3. Land deformation rate detection workflow of Sentinel 1A imagery.

Where;

$$
\text { Volume }=\left(\left|V_{I}\right| \cdot A_{1}+\left|V_{2}\right| \cdot A_{2} \ldots . .+\left|V_{n}\right| \cdot A_{n}\right) T
$$

$$
\begin{array}{lll}
\text { Volume } & =\text { Mined limestone volume in the span of time } \mathrm{T}\left(\mathrm{m}^{3}\right) \\
V_{n} & =\text { Land deformation rate with a negative value }(\mathrm{m} / \text { year) } \\
A_{n} & =\text { An area with land deformation rate of } \mathrm{V}_{\mathrm{n}}\left(\mathrm{m}^{2}\right) \\
T & =\text { Measured/observed land deformation's span of time (year) }
\end{array}
$$

\section{Results and discussion}

The limestone mining in the Klapanunggal Karst Landscape has been going on for over 45 years [12]. The environmental damage that can be observed from mining activities on the ground is the land destruction in the form of changes in land cover and landform. Using satellite imagery data from Landsat 8 and Sentinel $1 \mathrm{~A}$, this study shows that the detection of land cover and landform changes due to limestone mining activities in the Klapanunggal Karst Landscape is based on satellite imagery can be done.

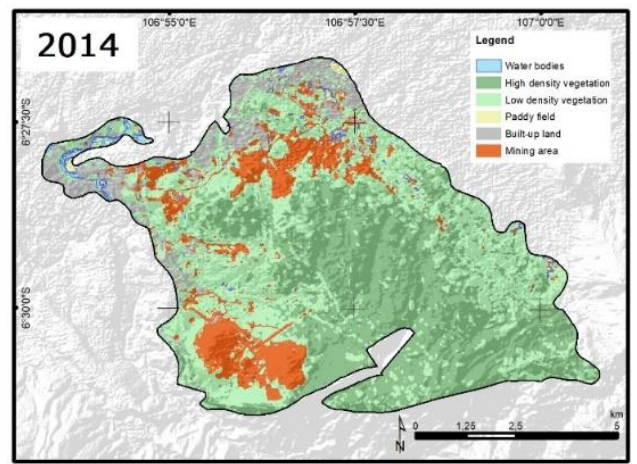

Fig. 4.A Map of Klapanunggal Karst Landscape's land cover in 2014.

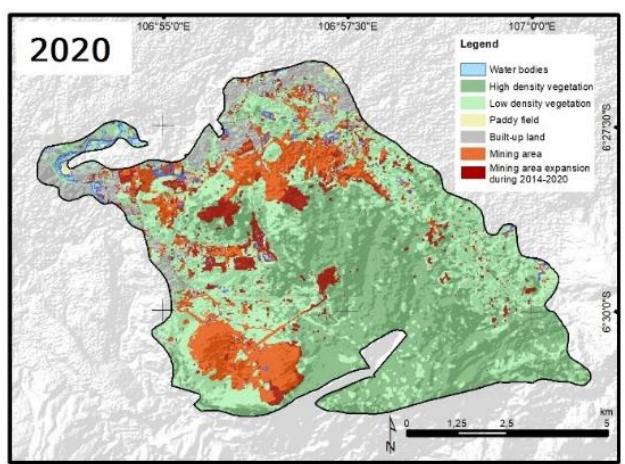

Fig. 4.B Map of widen area of limestone mining from 2014 to 2020 in Klapanunggal Karst Landscape.

Based on the results of the supervised classification of Landsat 8 imagery, limestone mining activities that took place from 1975 to 2014 have changed the land cover in the Klapanunggal Karst Landscape into a mine area without vegetation covering an area of 8.5 $\mathrm{x} 10^{6} \mathrm{~m}^{2}$ (Fig. 4.A). In addition, based on the comparison of the land cover map between 2014 and 2020, in a period of six years the mining activities had also converted the vegetated land cover into mined land with an area of $3.9 \times 10^{6} \mathrm{~m}^{2}$ (Fig. 4.B). On the other hand, the annual conversion rate of land covered by vegetation into mining land in the period 2014 2020 is around $6.7 \times 10^{5} \mathrm{~m}^{2} /$ year. Land cover change tends to be massive on the western side of the Klapanunggal Karst Landscape. Details of the amount of land cover conversion can be seen in Table 3.

Table 3. The area of vegetated land cover which converted due to limestone mining in the Klapanunggal Karst Landscape from 2014 to 2020.

\begin{tabular}{|l|c|}
\hline Converted land cover & Area $\left.\mathbf{( m}^{\mathbf{2}}\right)$ \\
\hline High-density vegetation & $9.4 \times 10^{5}$ \\
\hline Low-density vegetation & $3.0 \times 10^{6}$ \\
\hline
\end{tabular}


In addition, limestone mining activities in the Klapanunggal Karst Landscape have also contributed to landform change. Based on Sentinel 1A imagery data processing, land deformation occurred in all areas identified as mining areas in the 2014-2020 period with a negative rate trend (Fig. 5). This result indicates that the limestone mining activities on the ground have eroded (reduced the height) of the Klapanunggal Karst Landscape (Fig. 6A).

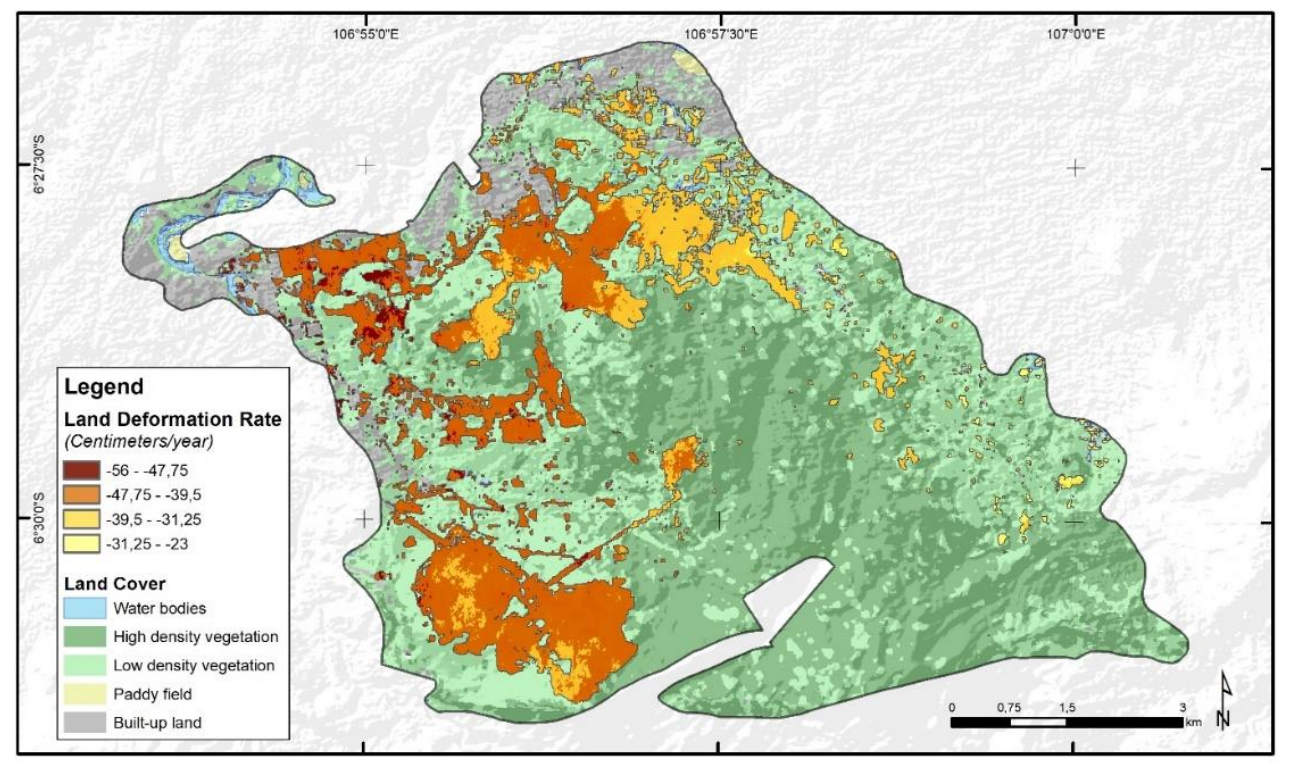

Fig. 5. Map of land deformation rate due to limestone mining activities in the 2014-2020 period in the Klapanunggal Karst Landscape.

Based on its area, land deformation with a rate range of -47.75 to $-39.50 \mathrm{~cm} /$ year followed by a rate of -39.50 to $-31.25 \mathrm{~cm} /$ year dominates landform changes with an area of $7.9 \times 10^{6}$ $\mathrm{m}^{2}$ and $4.0 \times 10^{6} \mathrm{~m}^{2}$, respectively (Table 4). Spatially, the deformation rate range of -47.75 to $-39.50 \mathrm{~cm} /$ year tends to be distributed on the west side of the mining area, while the deformation rate range of -39.50 to $-31.25 \mathrm{~cm} /$ year tends to be distributed on the east side of the mining area (Fig. 5).

Table 4. The area of deformed land due to limestone mining activities in the 2014-2020 period in the Klapanunggal Karst Landscape.

\begin{tabular}{|c|c|}
\hline Land deformation rate (cm/year) & Area $\left.\mathbf{( m}^{\mathbf{2}}\right)$ \\
\hline$-56,00--47,75$ & $4.2 \times 10^{5}$ \\
\hline$-47,75--39,50$ & $7.9 \times 10^{6}$ \\
\hline$-39,50--31,25$ & $4.0 \times 10^{6}$ \\
\hline$-31,25--23,00$ & $1.7 \times 10^{5}$ \\
\hline
\end{tabular}

Based on the information on land deformation rate (Table 4 and Fig. 5), by using the Equation (4), it can be estimated that in the 2014-2020 period, the volume of rock mined from the Klapanunggal Karst Landscape was $30.7 \times 10^{6} \mathrm{~m}^{3}$ (average $5.1 \times 10^{6} \mathrm{~m}^{3} /$ year). In comparison between Fig. 4 and Fig. 5, it can also be seen that $30.7 \times 10^{6} \mathrm{~m}^{3}$ was obtained 
from the area's extensification in new areas and intensification of mining in previously mined areas.

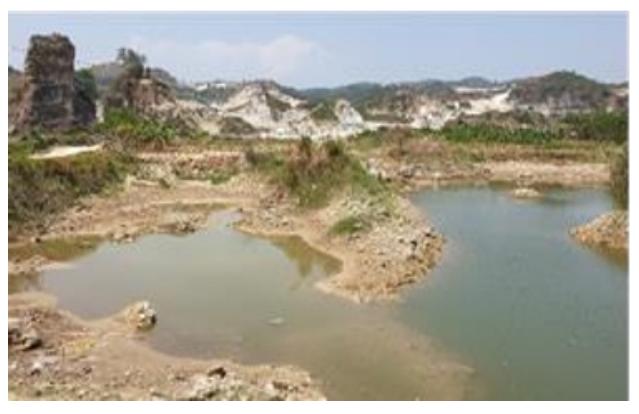

Fig. 6A. Land destruction condition due to limestone mining in the Klapanunggal Karst Landscape (location:-6.46182/106.95230, azimuth: $150^{\circ}$ ).

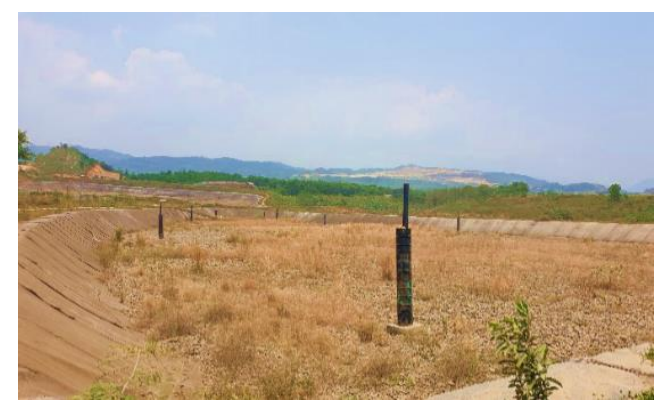

Fig. 6B. Use of ex-limestone mining land as a landfill (location: $-6.48496 / 106.93853^{\circ}$, azimuth:159).

Some constraints in this study are doing field surveys to validate the types of activities that cause destruction was not carried out in all areas. As so, it is much more possible that the land destruction detected in this study occurs not only as a result of mining. Examples of these cases are found in land cover and landform changes detected between 2014 and 2020, which is impacted by landfill construction (Fig. 6B). Besides, post-mining land that has been dormant for a long time so that it is re-covered with vegetation tends to cause areas affected by mining activities not to be detected optimally.

The advantages of spatial explanation in this study confirm the research result of Lamare and Singh (2016) that open limestone mining on the ground impacts changes in land cover and karst land formation [5]. Besides, this study also strengthens Pambudi et al. (2020) research findings in terms of the distribution of indications of mining areas in the Klapanunggal Karst Landscape, which is one of the high concentrations of $\mathrm{PM}_{10}$ agglomeration areas [6]. On the other hand, this study also extends the use of Sentinel 1A imagery in estimating land deformation caused by artificial factors on the land surface, in this case, limestone mining [32].

The detection of land cover and landform in the Klapanunggal Karst Landscape using freely available satellite imagery allows the community to monitor land destruction due to limestone mining activities in a participatory manner. In the future, the multispectral optical satellite imagery available since the late 1990s and SAR satellite images with the L-band wave-type available since 2007 can be optimized so that monitoring results become more comprehensive [33,34]. Methods of extracting land deformation information with a narrower time span such as Small Baseline Subset Interferometry (SBAS InSAR) can also be applied to produce a more accurate land deformation rate [35].

The next question arising from this research is related to the ideal time span to map land cover change of the mined area obscured by vegetation cover. In addition, considering that land destruction on the karst surface can threaten the existence of the epikarst layer, in further research, it is necessary to study the impact of 45 years old limestone mining on the karst hydrogeological system in the Klapanunggal Karst Landscape. 


\section{Conclusion}

Open limestone mining activities in Klapanunggal Karst Landscape are still carried out at surface level. Mining activities impact land destruction to the Klapanunggal Karst Landscape, especially regarding land cover changes and landform changes. Based on the results of detection using Landsat 8 imagery, it is known that the conversion of vegetated land into mining land, which is not covered by vegetation in the $2014-2020$ period is $4.0 \mathrm{x}$ $10^{6} \mathrm{~m}^{2}$ (average land cover conversion rate is $6.7 \times 10^{5} \mathrm{~m}^{2} /$ year). Furthermore, that tends to occur on the western side of the Klapanunggal Karst Landscape.

Based on the detection results using Sentinel 1A imagery, it is known that limestone mining activity in the period 2014 - 2020 has changed or eroded the landform. With a dominant deformation rate in the range of -47.75 to $-39.50 \mathrm{~cm} /$ year, located on the western side and ranges of -39.50 to $-31.25 \mathrm{~cm} /$ year located on the eastern side of the Klapanunggal Karst Landscape. In 2014 - 2020, an estimated $30.7 \times 10^{6} \mathrm{~m}^{3}$ (average $5.1 \times 10^{6} \mathrm{~m}^{3} /$ year) of limestone has been mined from the Klapanunggal Karst Landscape. Considering that land destruction on the karst surface can threaten the presence of epikarst layers, further research is needed to understand better the impact of land destruction due to limestone mining activities on the hydrogeological system in the Klapanunggal Karst Landscape.

\section{References}

1. C. Naydowski, P. HeB, D. Strauch, and R. Kuhlmann, in Calcium Carbonate From Cretac. Period into 21st Century, edited by F. W. Tegethof, 1st ed. (Birkhäuser Verlag, Basel, 2001), pp. 198-301

2. N. K. Mathur, S. R. Jakhar, and R. Mathur, Int. J. Sci. Res. 5, 2128 (2016)

3. J. E. Lamar and H. B. Willman, A Summary of the Uses of Limestone and Dolomite (Urbana, Illinois, 1938)

4. US Department of Energy, ITP Mining: Energy and Environmental Profile of the U.S. Mining Industry (n.d.)

5. R. E. Lamare and O. P. Singh, ENVIS Bull. Himal. Ecol. 24, (2016)

6. R. A. Pambudi, A. Naldi, A. Luthfi, D. A. Puspitarini, M. M. Chaerani, M. W. Permana, and S. Shafira, in Int. Conf. Sci. Appl. Geogr. (IOP Publishing, Depok, 2020), pp. 1-8

7. H. Haule, J. Ringo, K. Luvinga, S. Kawonga, G. Mayengo, and L. Morsardi, Int. J. Mod. Soc. Sci. 5, 117 (2016)

8. M. M. Robert and J. B. Michael, Underground Limestone Mining (Iowa, 1987)

9. J. D. Bliss, T. S. Hayes, and G. J. Orris, United States Geol. Surv. 1 (2012)

10. W. H. Langer, Potential Environmental Impacts of Quarrying Stone in Karst- A Literature Review (Virginia, 2002)

11. A. S. Djakamihardja and D. Mulyadi, Ris. Geol. Dan Pertamb. 23, 49 (2013)

12. G. Suhariyono, Characteristic Correlation of PM10 / PM2.5 Dust Particles and the Risk of Society Health at Dwelling around the Cement Industry (Study of Air Pollution Case at the Cement Factory, Citeureup - Bogor), Institut Pertanian Bogor, 2002

13. A. P. Cracknell, Int. J. Remote Sens. 39, 8387 (2018)

14. N. Horning, J. a Robinson, E. J. Sterling, W. Turner, and S. Spector, Remote Sensing for Ecology and Conservation., 1st ed. (Oxford University Press, Oxford, 2010)

15. R. W. Van Bemmelen, Geol. Indones. Volume IA, 637 (1949)

16. D. Balazs, in Karszt- És Barlangkutatás, edited by K. Hubert (Globus Nyomda, Budapest, 1968), pp. 3-61

17. Praptisih and Kamtono, Indones. J. Geosci. 1, 175 (2014)

18. Abdurrokhim, Bull. Sci. Contrib. Geol. 15, 167 (2017)

19. United States Geological Survey, Landsat 8 Data Users Handbook, 5th ed. (USGS, 
Sioux Falls, South Dakota, 2019)

20. European Space Agency, ESA Sentinel 1 Handbook (European Space Agency, Paris, 2013)

21. Ardiansyah, Pengolahan Citra Penginderaan Jauh, 1st ed. (Labsig Inderaja Islim, Jakarta, 2015)

22. G. Hasan and S. A. H. Saleh, J. Geophys. Remote Sens. 03, (2014)

23. H. K. Zhang and D. P. Roy, Remote Sens. 8, 1 (2016)

24. European Space Agency, Sentinel-1: ESA's Radar Observatory Mission for GMES Operational Services (ESA Communications, Leiden, 2012)

25. J. M. Wempen and M. K. McCarter, Int. J. Min. Sci. Technol. 27, 159 (2017)

26. R. F. Hanssen, Radar Interferometry: Data Interpretation and Error Analysis (Kluwer Academic Publihers, New York, 2001)

27. J. J. Sousa and L. Bastos, Nat. Hazards Earth Syst. Sci. 13, 659 (2013)

28. K. Fárová, J. Jelének, V. Kopačková-Strnadová, and P. Kycl, Remote Sens. 11, 1 (2019)

29. L. Veci, Sentinel-1 Toolbox TOPS Interferometry Tutorial (Array Systems Computing Inc, 2015)

30. L. Veci, Sentinel-1 Toolbox SAR Basics Tutorial (Array Systems Computing Inc, 2019)

31. Alaska Satellite Facility, Sentinel-1 InSAR Phase Unwrapping Using SITBX and SNAPHU (Alaska Satellite Facility, 2017)

32. Q. Wu, C. Jia, S. Chen, and H. Li, Remote Sens. 11, (2019)

33. A. Rosenqvist, M. Shimada, and M. Watanabe, Int. Symp. Retr. Bio- Geophys. Parameters from SAR Data L. Appl. 1, 1 (2004)

34. R. Bryant, M. S. Moran, S. McElroy, C. Holifield, K. Thome, and T. Miura, in Int. Geosci. Remote Sens. Symp. (2002), pp. 584-586

35. Y. Zhang, Y. Liu, M. Jin, Y. Jing, Y. Liu, Y. Liu, W. Sun, J. Wei, and Y. Chen, Sensors (Switzerland) 19, (2019) 